\title{
Protective effects of Stevia rebaudiana extracts on beta cells in lipotoxic conditions
}

\author{
Marco Bugliani ${ }^{1}$. Silvia Tavarini ${ }^{2}$. Francesca Grano ${ }^{1}$. Silvia Tondi ${ }^{3}$ Serena Lacerenza ${ }^{4} \cdot$ Laura Giusti $^{1,5}$. \\ Maurizio Ronci ${ }^{6} \cdot$ Anna Maidecchi $^{3} \cdot$ Piero Marchetti $^{1,6}$ (1) $\cdot$ Marta Tesi $^{1} \cdot$ Luciana G. Angelini $^{2,7}$
}

Received: 20 August 2020 / Accepted: 23 August 2021 / Published online: 9 September 2021

(c) The Author(s) 2021

\begin{abstract}
Aims Stevia rebaudiana Bertoni leaf extracts have gained increasing attention for their potential protection against type 2 diabetes. In this study, we have evaluated the possible beneficial effects of Stevia rebaudiana leaf extracts on beta-cells exposed to lipotoxicity and explored some of the possible mechanisms involved.

Methods Extracts, deriving from six different chemotypes (ST1 to ST6), were characterized in terms of steviol glycosides, total phenols, flavonoids, and antioxidant activity. INS-1E beta cells and human pancreatic islets were incubated $24 \mathrm{~h}$ with $0.5 \mathrm{mM}$ palmitate with or without varying concentrations of extracts. Beta-cell/islet cell features were analyzed by MTT assay, activated caspase 3/7 measurement, and/or nucleosome quantification. In addition, the proteome of INS-1E cells was assessed by bi-dimensional electrophoresis (2-DE).

Results The extracts differed in terms of antioxidant activity and stevioside content. As expected, $24 \mathrm{~h}$ exposure to palmitate resulted in a significant decrease of INS-1E cell metabolic activity, which was counteracted by all the Stevia extracts at $200 \mu \mathrm{g} / \mathrm{ml}$. However, varying stevioside only concentrations were not able to protect palmitate-exposed cells. ST3 extract was also tested with human islets, showing an anti-apoptotic effect. Proteome analysis showed several changes in INS-1E beta-cells exposed to ST3, mainly at the endoplasmic reticulum and mitochondrial levels.

Conclusions Stevia rebaudiana leaf extracts have beneficial effects on beta cells exposed to lipotoxicity; this effect does not seem to be mediated by stevioside alone (suggesting a major role of the leaf phytocomplex as a whole) and might be due to actions on the endoplasmic reticulum and the mitochondrion.
\end{abstract}

Keywords Stevia rebaudiana $\cdot$ Steviol glycosides $\cdot$ Beta cells $\cdot$ Lipotoxicity $\cdot$ Proteomics

\section{Introduction}

Type 2 diabetes (T2D) is the most common form of diabetes [1], and it is due to a complex interaction of genetic and acquired factors leading to beta-cell failure [2,3]. Among the acquired factors that are known to be associated with

Managed by Massimo Porta. $\mathrm{T} 2 \mathrm{D}$, an important role is played by the deleterious effects

Marco Bugliani, Silvia Tavarini: Equally contributed

Piero Marchetti

piero.marchetti@med.unipi.it

1 Department of Clinical and Experimental Medicine, University of Pisa, Pisa, Italy

2 Department of Agriculture, Food and Environment, University of Pisa, Pisa, Italy

3 Aboca SpA Società Agricola, Sansepolcro, Tuscany, Italy

4 Department of Pharmacy, University of Pisa, Pisa, Italy
5 School of Pharmacy, University of Camerino, Camerino, Italy

6 Department of Pharmacy and Centre for Advanced Studies and Technologies (CAST), University "G. D'Annunzio" of Chieti-Pescara, Chieti, Italy

7 Centro Interdipartimentale NUTRAFOOD, University of Pisa, Pisa, Italy 
of increased concentrations of glucose (glucotoxicity) and certain fatty acids (lipotoxicity) [4, 5]. Hence, many studies have tried to address how to protect beta cells from metabolic insults [5-9]. In this regard, Stevia rebaudiana Bertoni (Stevia), a native plant to the northeast of Paraguay, mainly known for its sweetener properties, has recently been shown to have beneficial effects in several models of disease and cellular dysfunction, including diabetes and beta cells [10-19]. Stevia leaf extracts represent, in fact, a unique Natural Complex Substance, thanks to the presence of steviol glycosides, phenolic acids, flavonoids, alkaloids, water-soluble chlorophylls, xanthophylls, hydroxycinnamic acids, minerals, and vitamins [20]. The majority of these phytochemicals have a wide variety of biological activities, which makes Stevia a plant source with potential benefits for human health [21]. Accordingly, Stevia's "antidiabetic" effects seem due to the bioactive compounds present in the medium-polar and aqueous extracts [22-24]. These effects are generally thought to be due to steviol glycosides, the molecules that confer sweet flavor to Stevia extracts, although also the non-sweetener fraction might display insulinotropic effects [22]. More than 30 steviol glycosides have been detected in Stevia leaves [23], but the most abundant are stevioside, rebaudioside $\mathrm{A}$ and rebaudioside $\mathrm{C}$. In literature, there are studies regarding the action of stevioside in stimulating insulin secretion, both in-vitro and invivo [24-32]. No data are currently available on the possible protective effects of Stevia extracts on pancreatic beta cells upon prolonged exposure to certain free fatty acids, also in relation to Stevia secondary metabolites - mainly steviol glycosides, polyphenols, and flavonoids-and their related antioxidant and ROS-scavenging activities. Therefore, the aim of this study was to evaluate the effects of leaf extracts from some Stevia rebaudiana Bertoni chemotypes, characterized by different phytochemical profiles, on betacells exposed to lipotoxic conditions. First, the leaf extracts were characterized in terms of total phenols and flavonoids, free radical-scavenging activity, total antioxidant capacity, steviol glycoside profile, and content. Then, the protective effects of Stevia leaf extracts were evaluated in INS-1E beta cells and human islets exposed to lipotoxicity. Finally, by proteomic analysis, we assessed the changes induced by Stevia in INS-1E cells.

\section{Materials and methods}

\section{Chemicals}

Ethanol and ferrous sulfate were purchased from Carlo Erba SpA (Milan, Italy). Water and acetonitrile were obtained from JT Baker (Phillipsburg, NJ, USA). Pure stevioside, rebaudioside $\mathrm{A}$, rebaudioside $\mathrm{B}$, rebaudioside $\mathrm{C}$, rebaudioside $\mathrm{D}$, dulcoside $\mathrm{A}$ and steviolbioside (97\% pure) were purchased from ChromaDex Inc. (Irvine, CA, USA). Gallic acid monohydrate (3,4,5-trihydroxy benzoic acid), TPTZ (2,4,6-tri(2-pyridyl)-s-triazine), Trizma acetate, Folin-Ciocalteu reagent, sodium carbonate, and ferric chloride were all obtained from Sigma-Aldrich Chemical Co. (Milan, Italy). All chemicals used in the present study, including solvents, were of analytical grade.

\section{Plant material}

Six stevia chemotypes (ST1 and ST2 from the germplasm collection of the Department of Agriculture, Food and Environment-DAFE; ST3, ST4, ST5, and ST6 from ABOCA germplasm collection) were used in this study. They were organically cultivated in open field conditions at the Experimental Centre of DAFE, located at San Piero a Grado, in Pisa coastal plain (Pisa, Central Italy $43^{\circ} 40^{\prime} \mathrm{N}$ of latitude and $10^{\circ} 20^{\prime} \mathrm{E}$ of longitude) following the Guidelines on Good Agricultural and Collection Practice (GACP) of the European Medicines Agency.

The leaves of each chemotype were collected at the end of the vegetative growth, before the start of flowering, when the content in bioactive compounds, especially steviol glycosides, was maximum. The leaves were dried in a ventilated oven at $40{ }^{\circ} \mathrm{C}$ until constant weight, ground to a fine powder in a laboratory mill, and kept in sealed bags at room temperature until the subsequent extraction procedure.

\section{Preparation of crude extracts}

The dried leaves of the six Stevia chemotypes were extracted using hydroalcoholic solvent (ethanol $50 \% \mathrm{v} / \mathrm{v}$ ) for $6 \mathrm{~h}$ at $40{ }^{\circ} \mathrm{C}$, by means of a Naviglio extractor, programmed with 51 cycles of $7 \mathrm{~min}$. The plant material/solvent ratio was $1 / 10$. Each cycle included a static phase of five min and a dynamic phase of two min, with 6 pumps $\mathrm{min}^{-1}$. The working pressure was 6-8 bar. The crude extract was centrifuged, dried under reduced pressure, and finally lyophilized to give an olive-green powder.

\section{Steviol glycoside analysis}

Steviol glycoside (SVgly) determination was performed according to Zimmermann et al. [33] and Tavarini et al. [20]. Operating HPLC conditions and chromatogram acquisition were based on the procedure described by Tavarini et al. [34]. SVgly composition and quantification were performed using a standard curve of an authentic standard mixture (0.05-0.5 $\left.\mathrm{g} \mathrm{L}^{-1}\right)$, containing stevioside, rebaudioside A, 
rebaudioside $\mathrm{B}$, rebaudioside $\mathrm{C}$, rebaudioside $\mathrm{D}$, dulcoside $\mathrm{A}$, and steviolbioside.

\section{Total phenolic content}

Total phenols were determined by the Folin-Ciocalteu method, according to Dewanto et al. [35] with some modifications [20]. In order to calculate the standard curve, gallic acid was used as an external standard. The results were expressed as $\mathrm{mg}$ gallic acid equivalent (GAE) $\mathrm{g}^{-1}$ of lyophilized extract.

\section{Total flavonoids determination}

Total flavonoids were spectrophotometrically determined using the method described by Barros et al. [36], based on the aluminum chloride assay. The measurements were taken at a wavelength of $510 \mathrm{~nm}$ using a UV-visible spectrophotometer (Varian Cary 1E, Palo Alto, CA U.S.A.). Catechin was used as an external standard to calculate the standard curve, and the results were expressed as mg of catechin equivalents (CE) $\mathrm{g}^{-1}$ of lyophilized extract.

\section{Ferric reducing antioxidant power (FRAP) assay}

Total antioxidant activity was determined based on the method by Benzie and Strain [37] with slight modifications [20]. Trolox was used as standard, and the final values were expressed as mmol Trolox equivalent (TE) $\mathrm{g}^{-1}$ of lyophilized extract.

\section{INS-1E beta cells and human islets}

INS-1E cells (a kind gift of prof. Claes B. Wollheim) were cultured in RPMI 1640 completed with $10 \%$ fetal bovine serum (Thermo Fisher Scientific, Paisley, UK), $10 \mathrm{mM}$ hepes (Sigma-Aldrich, Saint Louis, MO, USA), $100 \mathrm{mg} / \mathrm{ml}$ penicillin-streptomycin (Sigma-Aldrich), $1 \mathrm{mM}$ sodium pyruvate (Thermo Fisher Scientific), $50 \mu \mathrm{M}$ 2-mercaptoethanol (Thermo Fisher Scientific) at $37^{\circ} \mathrm{C}$ in $5 \% \mathrm{CO}_{2}$ atmosphere. Human islets were isolated from 9 non-diabetic organ donors (age: $72 \pm 12 \mathrm{y}$, gender: $5 \mathrm{M} / 4 \mathrm{~F}$; BMI: $26.3 \pm 4.7 \mathrm{~kg} \mathrm{~m}^{-2}$ ) by enzymatic digestion followed by density gradient purification, and cultured in M199 medium complete with $10 \%$ bovine serum and antibiotics, as previously described $[38,39]$, until the day of the experiment.

To evaluate the effects of the different extracts of stevia on beta cells, INS-1E cells were cultured $24 \mathrm{~h}$ in RPMI 1640 complete with $1 \%$ fatty acid-free BSA and $1 \%$ FBS with or without $0.5 \mathrm{mM}$ palmitate [39], in presence or not of increasing concentrations (from $10 \mu \mathrm{g} / \mathrm{ml}$ to $1000 \mu \mathrm{g}$ / $\mathrm{ml}$ ) of extracts. In other experiments, human islets were cultured for $24 \mathrm{~h}$ in presence of $0.5 \mathrm{mM}$ palmitate [4, 8 , 40] with or without $80 \mu \mathrm{g} / \mathrm{ml}$ of a stevia extract in M199 medium completed with antibiotics and $1 \%$ fatty acid-free BSA.

\section{MTT assay}

Cell viability was monitored indirectly through the MTT assay [41, 42]. This assay estimates cell metabolic efficiency by exploiting the ability of the mitochondrial enzyme $\mathrm{NAD}(\mathrm{P}) \mathrm{H}$-dependent cellular oxidoreductase enzymes to reduce the 3-(4,5-dimethylthiazol-2-yl)-2,5-diphenyltetrazolium bromide salt (MTT) to its insoluble derivative formazan, which has a purple color. Briefly, a solution containing $5 \mathrm{mg} / \mathrm{ml}$ of tetrazolium bromide salt (Sigma-Aldrich) dissolved in PBS was added to the cells exposed to each condition to get a final concentration of $0.5 \mathrm{mg} / \mathrm{ml}$. Then, the plate was kept in an incubator at $37^{\circ} \mathrm{C}$ and $5 \% \mathrm{CO}_{2}$ for $3 \mathrm{~h}$. In the end, the supernatant was aspirated, and the formed salt dissolved in DMSO. After 20 min of shaking, the plate was read in a plate reader at $570 \mathrm{~nm}$ with a baseline at $650 \mathrm{~nm}$. The viability was calculated as a percentage of absorbance with respect to untreated cells.

\section{Apoptosis evaluation}

Human islet cell apoptosis was evaluated by caspase activation and an ELISA method. Caspase 3/7 activity was measured by Caspase-Glo ${ }^{\circledR}$ 3/7 Assay (Promega Corporation, Madison, WI, USA) following the manufacturer protocol. Briefly, 15 hand-picked islets were cultured in lipotoxic conditions (3-5 experimental points for each condition) and then a working solution containing a tetrapeptide linked to aminoluciferin was added to the cultured cells. Following caspase cleavage of the substrate, aminoluciferin is released and, in the presence of luciferase and ATP, results in the luciferase reaction and production of light which, in turn, can be detected by a luminometer. In additional sets of experiments, apoptosis was also evaluated by Cell Death Detection Elisa ${ }^{\text {Plus }}$ kit (Roche Diagnostics, Mannheim, Germany) as per manufacturer indications.

\section{Proteome analysis}

INS-1E cultured $24 \mathrm{~h}$ in presence of $200 \mu \mathrm{g} / \mathrm{ml}$ of ST3 were washed twice with PBS $\left(37^{\circ} \mathrm{C}\right)$, suspended in the rehydration solution (7 M urea, $2 \mathrm{M}$ thiourea, $4 \%$ CHAPS, $60 \mathrm{mM}$ DTT, $0.002 \%$ bromophenol blue), and incubated for $1 \mathrm{~h}$ at room temperature (RT). Thereafter, the samples were centrifuged at 13,000 $\mathrm{g}$ for $10 \mathrm{~min}$ at RT to remove undissolved material. In order to remove all the interfering substances, 
the samples have been treated with 2-D Clean-Up Kit (GE Health Care Europe; Uppsala, Sweden) using manufacture instructions. Protein concentration of the resulting supernatant was determined using the Bio-Rad RC/DC-protein assay (Bio-Rad, Hercules, CA, USA) with BSA as a standard [43]. 2-DE analysis was performed on beta-cell protein extracts. Briefly, $200 \mu \mathrm{g}$ of proteins were filled up to $450 \mu \mathrm{L}$ in rehydration solution supplemented with $0.8 \%$ v/v IPG Buffer, $\mathrm{pH}$ 3-10 NL (GE Healthcare), and 1\% (v/v) Pharmalyte 3-10. Immobilien Dry-Strips (GE Health Care Europe; Uppsala, Sweden), $18 \mathrm{~cm}$, nonlinear gradient $\mathrm{pH}$ 3-10 were rehydrated overnight in the sample and then transferred to the Ettan IPGphor II apparatus (GE Health Care). Isoelectrofocusing (IEF) was performed at $16{ }^{\circ} \mathrm{C}$ and the proteins were focused for up to $70000 \mathrm{Vh}$. The second dimension (Sodium Dodecyl Sulphate-Polyacrylamide Gel Electrophoresis; SDS-PAGE) was carried out by transferring the proteins to $12.5 \%$ polyacrylamide gel, running at $16 \mathrm{~mA} / \mathrm{gel}$ and $12{ }^{\circ} \mathrm{C}$ for about $16 \mathrm{~h}$. The gels were stained with Ruthenium II tris (bathophenanthroline disulfonate) tetrasodium salt (SunaTech Inc.; Suzhou, P. R. China) (RuBP) as previously described [43]. Gel images were acquired by "Image Quant LAS4010" and the analysis of 2-DE images was performed using the Same Spot (v4.1, TotalLab; Newcastle Upon Tyne, UK) software. A comparison between cells treated with and without ST3 was performed. The spot volume ratios between the two different conditions were calculated using the average spot normalized volume of the three biological replicates. The software included statistical analysis calculations. The protein spots of interest with $p<0.05$, were cut out from the gel, trypsin digested, and identified by Nanoliquid chromatography-electrospray ionization tandem mass spectrometry (nano-LC-ESI-MS/MS) analysis as previously described [44]. DataAnalysis v. 4.2 was used to process the raw data and generate the peak list to be submitted to the database search through BioTools 3.2 exploiting the free version of MASCOT search engine against Uniprot/Swiss-Prot non-redundant database version 2014-11. Rattus norvegicus taxonomy was specified for database searching [43]. Protein-protein interaction networks were analyzed using string software (string-db.org/). Confidence view was assigned a score of 0.4 , indicating medium confidence.

\section{Statistical analysis}

Data from phytochemical screening were subjected to analysis of variance (ANOVA) using CoStat version 6.2 (CoHort Software, Monterey, CA, USA). One-way completely randomized ANOVA was carried out to estimate the effect of biotype, followed by least significant difference (LSD) posthoc test. $p<0.05$ was considered to indicate statistical significance. Prior to ANOVA, inhibition percentage data were subjected to an arcsine transformation. Cellular data were presented as mean \pm SEM. To represent the results of this part of the study, data from control experiments were expressed as $100 \%$ at each given condition. The effects of the perturbators were then expressed for each experiment as variation from the respective control values. Differences between the groups were analyzed by ANOVA followed by Bonferroni correction or Dunnet T3 test as appropriate. A $p$-value $<0.05$ was considered statistically significant.

\section{Results}

\section{Phytochemical evaluation of the stevia leaf extracts}

The tested Stevia chemotypes showed significant differences in terms of phytochemical composition (Table 1). ST2 was characterized by the highest content of phenols and flavonoids, while ST5 and ST6 showed the lowest content. Accordingly, ST2 reached a significantly higher total antioxidant activity (FRAP), and both ST5 and ST6 extracts exhibited the lowest antioxidant values (Table 1). Regarding the total steviol glycoside content, both ST1 and ST3 showed the highest amount, while ST4 extract was characterized by the lowest content (Table 1). The profile of the main steviol glycosides is reported in Table 2 . The most abundant of them were, as expected, stevioside, rebaudioside A, and rebaudioside $\mathrm{C}$. The content of the most known compound, stevioside, was highest in ST3 extract and lowest in ST2 and ST4 extracts.

Taken together, these results underline the influence of the chemotype (i.e. a chemically distinct biotype with differences in the composition of the secondary metabolites) in defining the phytochemical composition of stevia leaf extracts.

\section{Direct effects of stevia extracts and stevioside on INS-1E and human islet cells}

Taking into account the phytochemical composition of the extracts, we decided to test the effects of extracts with different antioxidant activity and stevioside content (namely ST2, ST3, and ST4) on INS-1E cells indirectly measuring cell viability with the use of MTT. After $24 \mathrm{~h}$ incubation, no sign of cytotoxicity was observed for concentrations of the extracts ranging from $10 \mu \mathrm{g} / \mathrm{ml}$ to $1000 \mu \mathrm{g} / \mathrm{ml}$. Cell metabolic activity increased with 200 and $500 \mu \mathrm{g} / \mathrm{ml}$ for ST2, 150, 200, and $500 \mu \mathrm{g} / \mathrm{ml}$ for ST3 and from 50 to $200 \mu \mathrm{g} / \mathrm{ml}$ for ST4 (Fig. 1, panels A-C). Based on these results, we decided to use a concentration in the lower range $(50 \mu \mathrm{g} / \mathrm{ml})$ and one in the higher range $(200 \mu \mathrm{g} / \mathrm{ml})$ to assess the effects of the extracts against lipotoxicity. Palmitate exposure induced a reduction of beta-cell metabolic activity ranging, approximately, $20-40 \%$ compared to control samples. A beneficial 
Table 1 Total phenols, total flavonoids, total antioxidant activity (measured by FRAP assay), and total SVgly content in the leaf extracts of the six stevia chemotypes

\begin{tabular}{|c|c|c|c|c|}
\hline & $\begin{array}{l}\text { Total Phenols (mg } \\
\left.\text { GAE } \mathrm{g}^{-1} \mathrm{LE}\right)\end{array}$ & $\begin{array}{l}\text { Total Flavonoids(mg } \\
\left.\mathrm{CE} \mathrm{g}^{-1} \mathrm{LE}\right)\end{array}$ & FRAP (mmol TE g $\left.{ }^{-1} \mathrm{LE}\right)$ & $\begin{array}{l}\text { Total SVglys } \\
\left(\mathrm{g} 100 \mathrm{~g}^{-1}\right. \\
\mathrm{LE})\end{array}$ \\
\hline ST1 & $154.99 \pm 6.66^{\mathrm{a}}$ & $128.08 \pm 0.81^{\mathrm{a}}$ & $1.51 \pm 0.08^{\mathrm{a}}$ & $40.57 \pm 0.13^{\mathrm{e}}$ \\
\hline ST2 & $175.95 \pm 2.40^{\mathrm{a}}$ & $150.24 \pm 4.57^{\mathrm{a}}$ & $2.31 \pm 0.10^{\mathrm{a}}$ & $35.58 \pm 0.09^{f}$ \\
\hline ST3 & $117.72 \pm 2.88^{\mathrm{a}}$ & $105.34 \pm 5.80^{\mathrm{a}}$ & $1.25 \pm 0.06^{\mathrm{a}}$ & $40.88 \pm 0.06^{\mathrm{e}}$ \\
\hline ST4 & $93.39 \pm 4.17^{\mathrm{a}}$ & $39.46 \pm 0.94^{\mathrm{c}}$ & $0.94 \pm 0.3 \cdot 10^{-1 \mathrm{a}}$ & $28.04 \pm 0.59^{\mathrm{a}}$ \\
\hline ST5 & $63.01 \pm 2.48^{\mathrm{b}}$ & $31.04 \pm 0.09^{\mathrm{d}}$ & $0.68 \pm 0.02^{\mathrm{b}}$ & $33.25 \pm 0.35^{\mathrm{a}}$ \\
\hline ST6 & $64.39 \pm 0.50^{\mathrm{b}}$ & $28.32 \pm 0.97^{\mathrm{b}}$ & $0.59 \pm 0.01^{b}$ & $34.67 \pm 0.27^{\mathrm{f}}$ \\
\hline $\begin{array}{l}\text { One-way } \\
\text { ANOVA }\end{array}$ & $p<0.001$ & $p<0.001$ & $p<0.001$ & $p<0.001$ \\
\hline
\end{tabular}

Results are the means $(n=3) \pm$ SE. A one-way ANOVA was used to evaluate the effect of chemotype. The LSD post-hoc test was also used:

${ }^{\text {a }}$ Significantly different versus all the other values within the column;

${ }^{\mathrm{b}}$ Significantly different versus ST1-ST4 within the column;

'Significantly different versus ST1-ST3 and ST6 within the column;

${ }^{\mathrm{d}}$ Significantly different versus ST1-ST3 within the column;

${ }^{\text {e}}$ Significantly different versus ST2 and ST4-ST6 within the column;

${ }^{\mathrm{f}}$ Significantly different versus ST1 and ST3-ST5 within the column

FRAP ferric reducing antioxidant power, SVgly steviol glycoside, GAE gallic acid equivalent, LE lyophilized extract, $C E$ catechin equivalents, $T E$ Trolox equivalent, $L S D$ least significant difference

Table 2 Concentration of the main SVglys identified in leaf extracts of the six stevia chemotypes

\begin{tabular}{llllll}
\hline & Stbio $\left(\mathrm{g} 100 \mathrm{~g}^{-1} \mathrm{LE}\right)$ & Dulc A $\left(\mathrm{g} 100^{-1} \mathrm{LE}\right)$ & Stev $\left(\mathrm{g} 100 \mathrm{~g}^{-1} \mathrm{LE}\right)$ & \left.${\operatorname{Reb~C}\left(\mathrm{g} 100 \mathrm{~g}^{-1} \mathrm{LE}\right)}_{\mathrm{Reb} \mathrm{A}(\mathrm{g} \mathrm{100} \mathrm{g}}^{-1} \mathrm{LE}\right)$ \\
\hline ST1 & $1.94 \pm 0.01^{\mathrm{a}}$ & $4.59 \pm 0.01^{\mathrm{a}}$ & $12.81 \pm 0.08^{\mathrm{a}}$ & $10.40 \pm 0.05^{\mathrm{d}}$ & $10.83 \pm 0.09^{\mathrm{a}}$ \\
ST2 & $1.18 \pm 0.03^{\mathrm{b}}$ & $6.43 \pm 0.05^{\mathrm{a}}$ & $9.64 \pm 0.05^{\mathrm{c}}$ & $10.46 \pm 0.03^{\mathrm{d}}$ & $7.87 \pm 0.02^{\mathrm{a}}$ \\
ST3 & $1.14 \pm 0.01^{\mathrm{b}}$ & $4.16 \pm 0.01^{\mathrm{a}}$ & $22.41 \pm 0.05^{\mathrm{a}}$ & $3.03 \pm 0.01^{\mathrm{e}}$ & $10.14 \pm 0.02^{\mathrm{a}}$ \\
ST4 & $0.83 \pm 0.01^{\mathrm{a}}$ & $2.61 \pm 0.08^{\mathrm{a}}$ & $9.28 \pm 0.52^{\mathrm{c}}$ & $6.09 \pm 0.25^{\mathrm{a}}$ & $9.23 \pm 0.10^{\mathrm{f}}$ \\
ST5 & $1.34 \pm 0.05^{\mathrm{a}}$ & $1.66 \pm 0.03^{\mathrm{a}}$ & $17.43 \pm 0.28^{\mathrm{a}}$ & $3.39 \pm 0.19^{\mathrm{e}}$ & $9.43 \pm 0.08^{\mathrm{f}}$ \\
ST6 & $5.33 \pm 0.09^{\mathrm{a}}$ & $3.02 \pm 0.02^{\mathrm{a}}$ & $15.31 \pm 0.23^{\mathrm{a}}$ & $2.07 \pm 0.10^{\mathrm{a}}$ & $8.94 \pm 0.08^{\mathrm{a}}$ \\
One-way & $p<0.001$ & $p<0.001$ & $p<0.001$ & $p<0.001$ & $p<0.001$ \\
ANOVA & & & & & \\
\hline
\end{tabular}

Results are the means $(n=3) \pm$ SE. A one-way ANOVA was used to evaluate the effect of the biotype. The LSD post-hoc test was also used: ${ }^{a}$ Significantly different versus all the other values within the column;

${ }^{\mathrm{b}}$ Significantly different versus ST1 and ST4-ST6 within the column;

${ }^{\mathrm{c}}$ Significantly different versus ST1, ST3 and ST5-ST6 within the column;

${ }^{\mathrm{d}}$ Significantly different versus ST3-ST6 within the column;

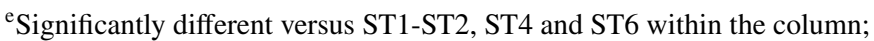

${ }^{\text {f }}$ Significantly different versus ST1-ST3 and ST6 within the column

SVglys steviol glycosides, Stbio steviolbioside, Dulc A dulcoside A, Stev stevioside, Reb C rebaudioside C, Reb A rebaudioside A, LE lyophilized extract, $L S D$ least significant difference

effect was observed for ST3 and ST4 at $50 \mu \mathrm{g} / \mathrm{ml}$ and for all the 3 extracts at $200 \mu \mathrm{g} / \mathrm{ml}$ (Fig. 1, panels D-F).

Since ST3 was able to prevent the detrimental action of palmitate both at 50 and $200 \mu \mathrm{g} / \mathrm{ml}$, we assessed whether a similar positive effect could be reproduced also on human islets exposed to the lipotoxic condition in the presence of an intermediate concentration of the extract $(80 \mu \mathrm{g} / \mathrm{ml})$. By a luminescent technique, it was observed that palmitate treatment induced significant activation of caspase 3/7, which was prevented by the presence of ST3 (Fig. 2, panel A). In addition, there was a threefold increase of apoptosis in palmitate-treated islets, which was prevented by ST3 cotreatment (Fig. 2, panel B).

In order to assess whether the observed positive effects of stevia extracts could be mediated, at least in part, by stevioside, we evaluated beta-cell viability on INS-1E cells 
A

Stevia 2

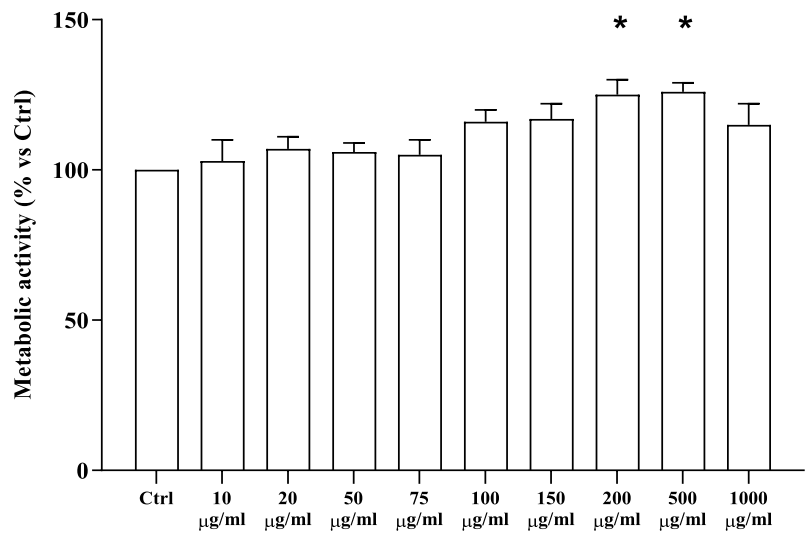

B

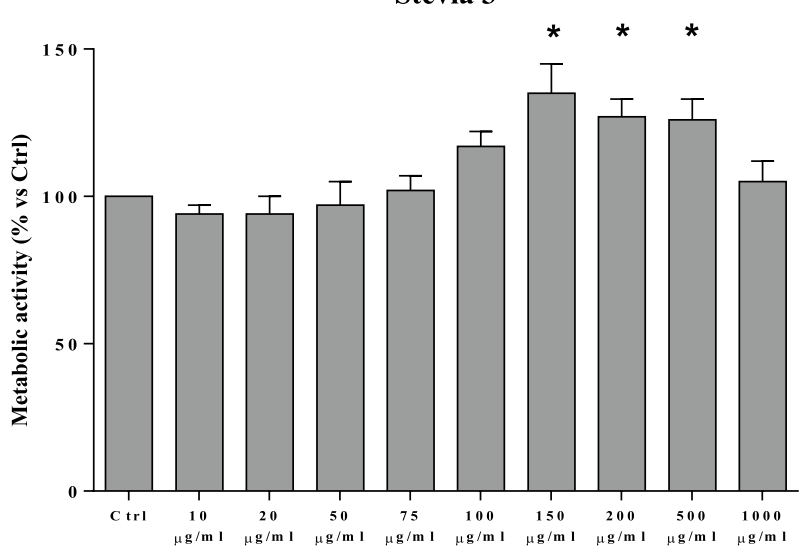

C

Stevia 4

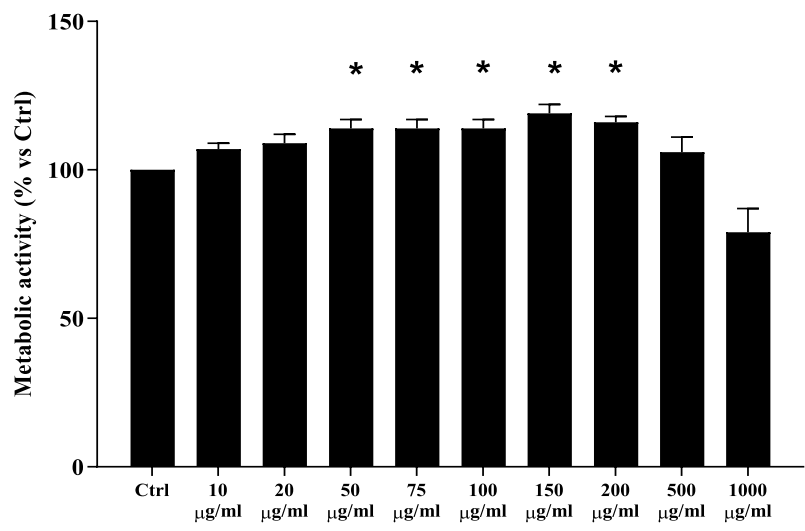

Fig. 1 Metabolic activity of INS-1E cells exposed to increasing concentrations of the different stevia extracts (Panels A, B and C). ${ }^{*} p<0.05$ vs Ctrl by ANOVA followed by Dunnet's T3 test. Effects of different stevia extracts on INS-1E cells cultured $24 \mathrm{~h}$ in $0.5 \mathrm{mM}$

exposed to palmitate, with or without increasing concentrations of this compound. As shown in Fig. 3, palmitateinduced a marked reduction of metabolic activity, and the
D

Stevia 2

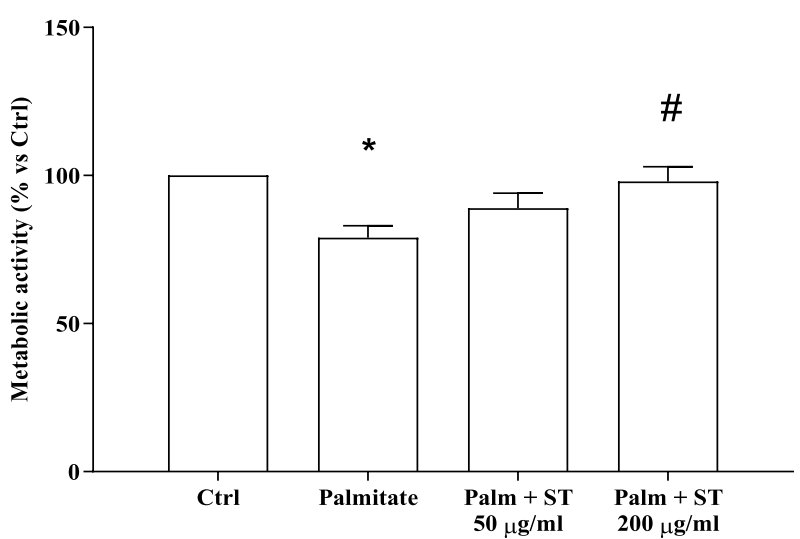

$\mathbf{E}$

Stevia 3

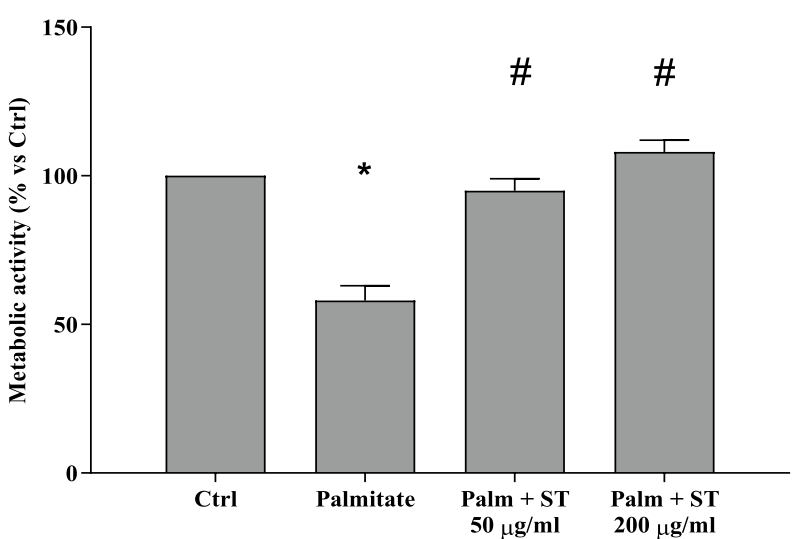

$\mathbf{F}$

Stevia 4

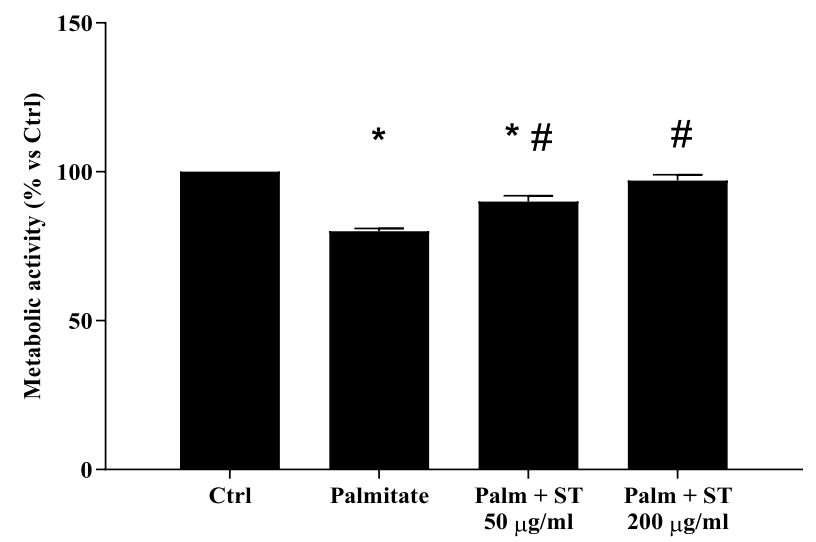

palmitate (Panels D, E, and $\mathrm{F}$ ). ${ }^{*} p<0.05$ versus $\mathrm{Ctrl} ; \# p<0.05$ versus Palmitate by ANOVA followed by Dunnet's T3 test. Data refer to 3 separate experiments, each consisting of 5 replicates

presence of stevioside at the tested concentrations did not prevent this detrimental effect. 
$\mathbf{A}$

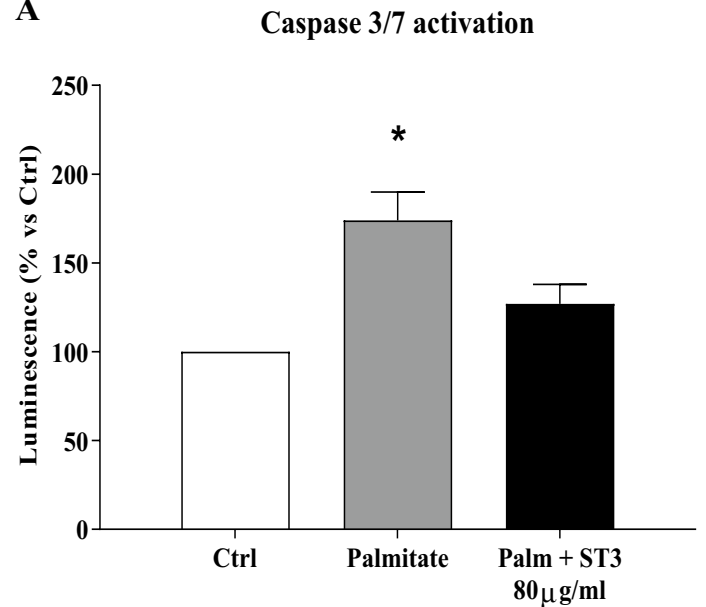

Fig. 2 Caspase 3/7 activation in human islets exposed to $0.5 \mathrm{mM}$ palmitate with (black bar) or without (grey bar) the presence of $80 \mu \mathrm{g} /$ $\mathrm{ml}$ of stevia 3 (ST3) extract. * $p<0.05$ versus Ctrl by ANOVA followed by Dunnet's T3 test (panel A). Islet cell death measured by oligonucleosome evaluation in human islets exposed to $0.5 \mathrm{mM}$ pal-

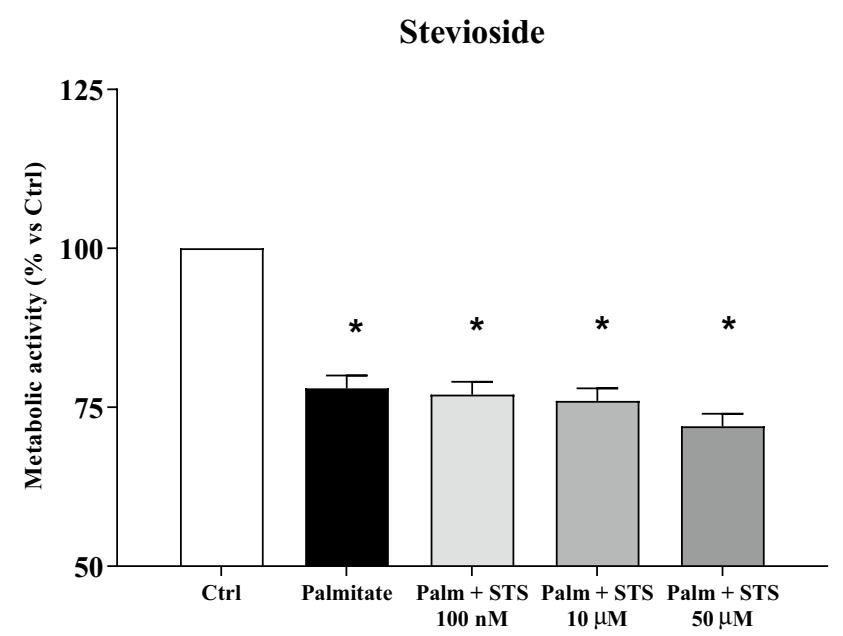

Fig. 3 Effect of increasing concentrations of stevioside (STS) on the metabolic activity of INS-1E cells exposed for $24 \mathrm{~h}$ to $0.5 \mathrm{mM}$ palmitate, measured by MTT assay. $* p<0.05$ versus Ctrl by ANOVA followed by Dunnet's T3 test. Data refer to 3 separate experiments, each consisting of 5 replicates

\section{Proteomic studies}

To get some insights on the mechanisms involved in the effects of stevia extracts, we analyzed the proteome modification induced in INS-1E by $24 \mathrm{~h}$ exposure to $200 \mu \mathrm{g} / \mathrm{ml}$ of ST3. A representative image of beta-cell protein extract is shown in Fig. 4. After computational comparison of images obtained by treated and untreated beta-cell protein extracts, 22 spots resulted to be differentially expressed (fold change $>1.7$ ). Of them, 10 were increased and 12 decreased

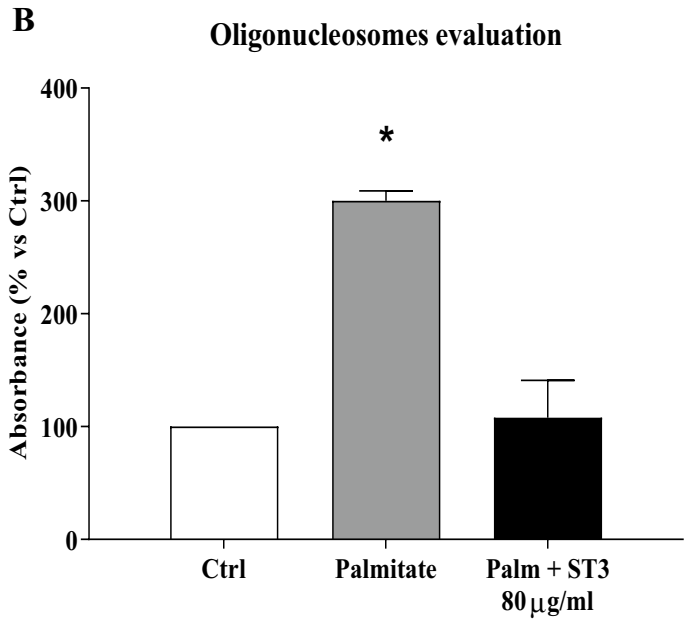

mitate with (black bar) or without (grey bar) the presence of $80 \mu \mathrm{g}$ / $\mathrm{ml}$ of ST3 extract. ${ }^{*} p<0.05$ versus all groups by ANOVA followed by Dunnet's T3 test (panel B). Data refer to 3-5 experiments, each consisting of 3 replicates

after treatment with ST3. Figure 5 reports bar charts of the spots found differentially expressed and Table 3 shows the list of the identified proteins (more than one identification was displayed for the spots $3788,693,1210,1147$, and 1997), MS/MS results, protein expression ratio, $p$-values and subcellular localization. Interestingly, most of them are associated with the endoplasmic reticulum and the mitochondrion (Table 3).

To investigate the relationship between the differentially expressed proteins, protein-protein interactions were analyzed by STRING software. The STRING network analysis (Fig. 6) described pathways associated with protein folding, metabolism of proteins, and response to endoplasmic reticulum stress.

\section{Discussion}

This study describes the phytochemical characteristics of several different Stevia leaf extracts and reports on the direct protective actions of some of such extracts on beta-cells exposed to lipotoxicity.

To date, most studies on the action of Stevia on beta cells have addressed insulin secretory features [10, 13, 17-19, 22, $25,27-32]$. In our study, we focused on parameters markers of cell survival/death, which were evaluated in a beta-cell line (INS-1E) and isolated human islets. These two models are often combined to provide basic information and potential translational insights $[39,45]$. In addition, although human islets are heterogeneous due to the presence of different endocrine cells, beta cells are the most represented 


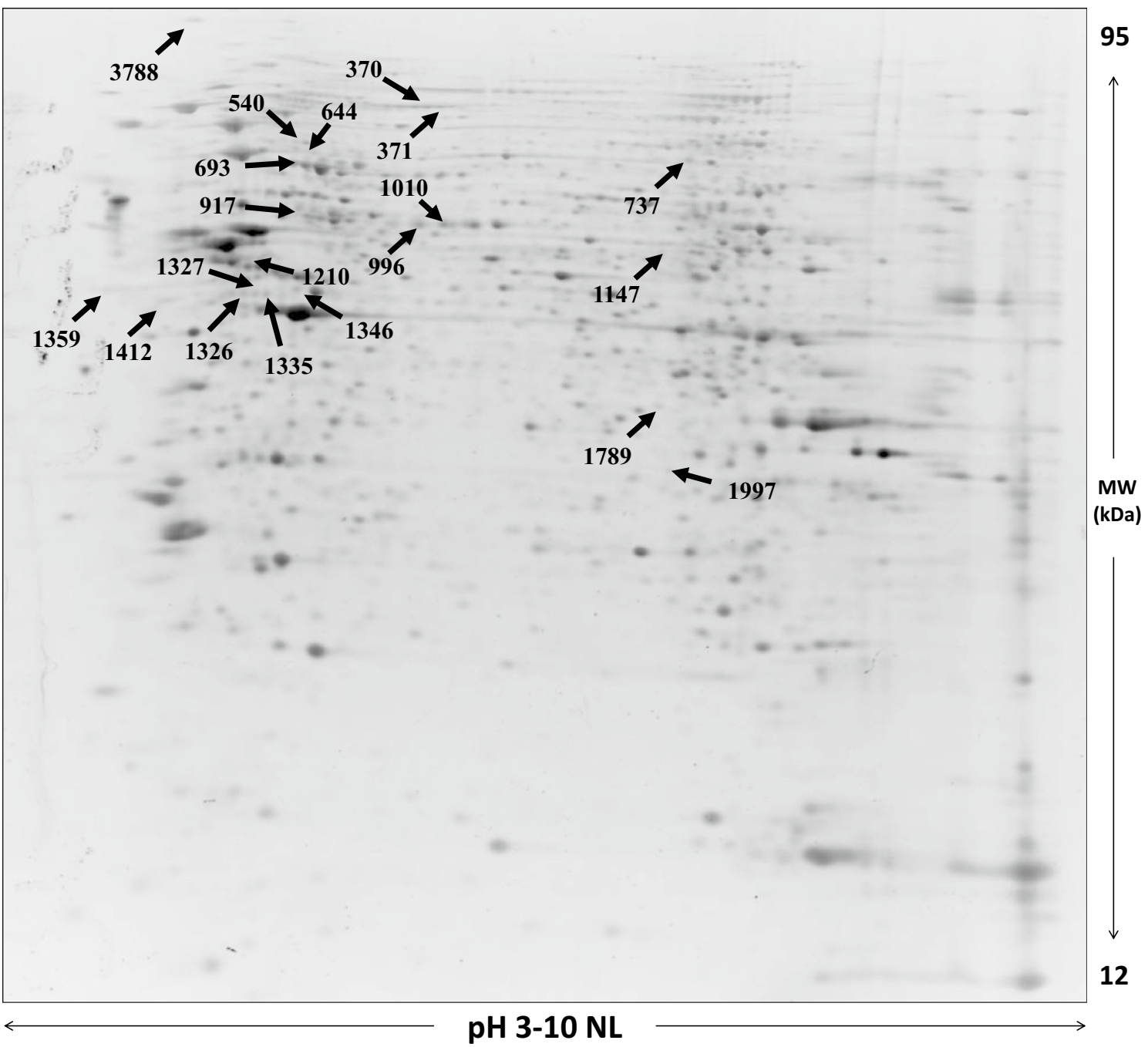

Fig. 4 Representative 2D gel map of INS-1E beta cells. The number indicates the proteins identified by nano LC-ESI MS/MS and reported in Table 3

ones and evidence exists to indicate that they are the islet cells most susceptible to palmitate-induced damage [46, 47].

The six chemotypes that we studied (named ST1 to ST6) showed apparent differences in their chemical composition and properties. These include the levels of phenols, flavonoids and steviol glycosides, and antioxidant activity. Such differences can be due to genetic characteristics, as well as cultivation factors [48, 49]. In particular, we observed that ST2 was characterized by the highest content of phenols and flavonoids as well as high antioxidant activity, ST1 and ST3 showed the highest steviol glycoside concentration, ST4 exhibited the lowest quantity of glycosides, whereas ST5 and ST6 had the lowest antioxidant properties. Despite these differences, extracts with different phytochemical composition (ST2, ST3, and ST4 in the present study) demonstrated similar effects on the viability of INS-1E beta cells, leading to an improvement of the metabolic activity of the cells at similar concentrations. This is in line and implements previous evidence generated in-vitro and in-vivo with fewer and less characterized Stevia extracts [10, 13, 17-19, 22, 25, 27-32].

Interestingly, the ST2, ST3, and ST4 chemotypes were able to similarly protect INS-1E beta cells from the lipotoxic action due to prolonged exposure to the saturated fatty acid, palmitate. Indeed, palmitate reduced cell viability by $20-40 \%$, confirming previous work with this model $[39,50$, 51]. However, the presence of ST2, ST3, and ST4 prevented palmitate-induced beta-cell damage in INS-1E beta cells. To assess if specific Stevia extract components were responsible for this protective effect, INS-1E, treated with palmitate, were exposed to stevioside only. This main stevia component has been shown to ameliorate insulin secretion in INS-1E cells exposed to palmitate or high glucose concentrations by different mechanisms [27, 28]. However, in our study, we did 


\section{Altered spots}

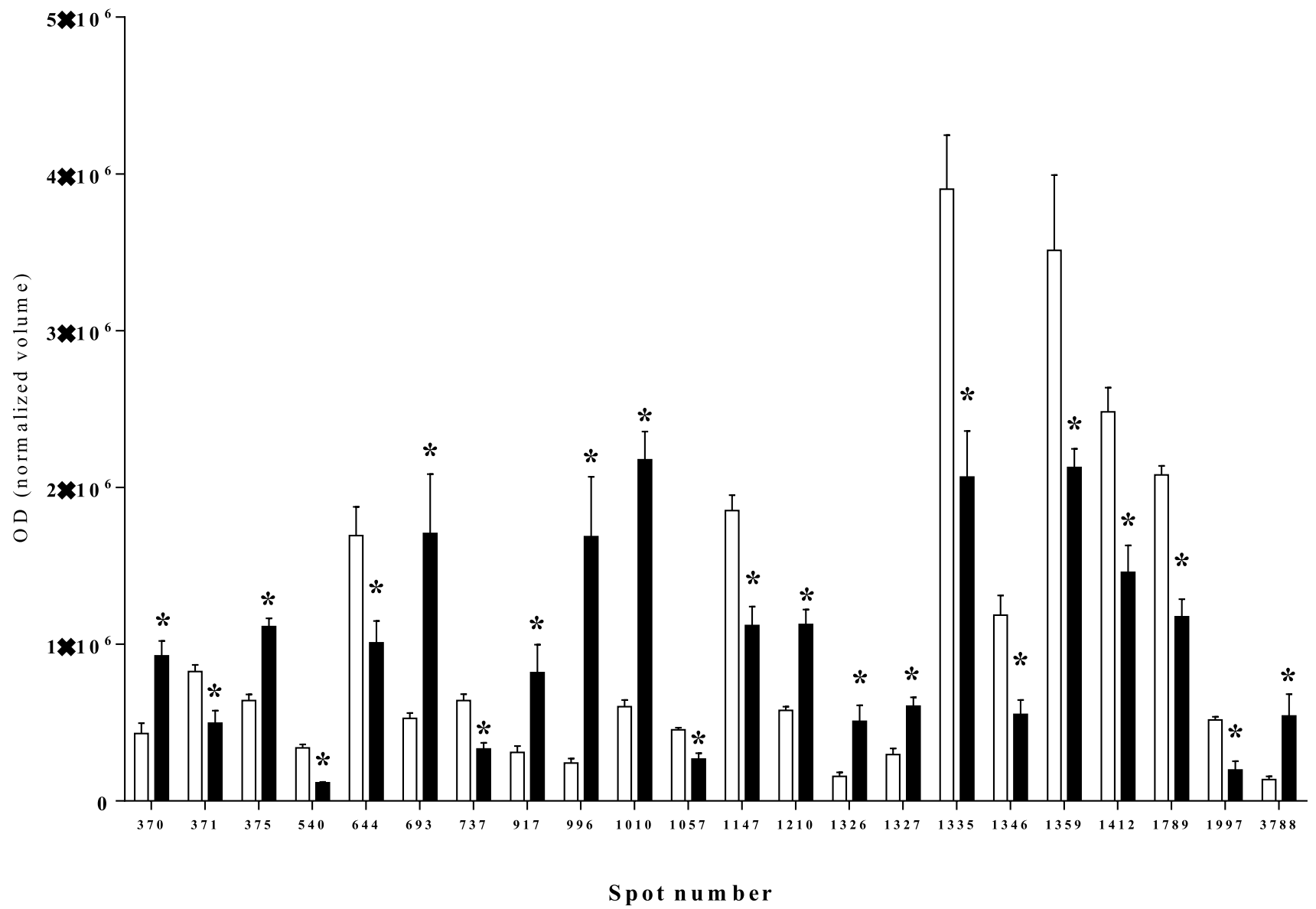

Fig. 5 Histograms of the normalized OD density volumes of the protein spots found significantly different in stevia-treated INS-1E beta cells (black bars) with respect to untreated cells (white bars). $* p<0.05$ versus untreated cells by ANOVA

not observe any evidence of protection by stevioside alone against palmitate-induced beta-cell death, suggesting that the improvement of beta-cell survival is likely due to combinations of Stevia components or the phytocomplex in toto.

Of note, ST3 showed similar beneficial actions with human islets under palmitate exposure, leading to reduced caspase 3/7 activation and reduced islet cell apoptosis. These novel findings support the consideration of Stevia extracts as potential tools to sustain beta-cell survival.

However, from our experiments, it is not possible to infer the possible therapeutic blood concentrations of Stevia leaf extracts or stevioside in the clinical setting. We are not aware of pharmacokinetics/pharmacodynamics studies evaluating such a point with leaf extracts. A previous report showed that after oral administration of $375 \mathrm{mg}$ stevioside, 60-180 min postdose the circulating concentration of the compound was $0.1 \mu \mathrm{g} / \mathrm{ml}$ [52].

Palmitate exposure alters several aspects of beta-cell function and survival, inducing a series of detrimental effects identified with the term "lipotoxicity". The main markers of lipotoxicity are ER stress and mitochondrial dysfunction. Palmitate triggers ER stress, affecting ER folding capacity and inducing overload of misfolded protein, and increase ROS production, causing mitochondrial dysfunction [3-5, $8,39,40,43,47,50,51,53]$. Of interest, our proteomic results showed that the ST3 extract regulates the expression of proteins related to ER and mitochondria. More specifically, it was observed an increased expression of proteins, such as HSPD1, PDIA3, PDIA6, HSPA8, and 9 ERP44 that facilitate protein folding by binding to nascent proteins and inhibiting the aggregation of misfolded proteins [54-59]. Furthermore, we found that ST3 exposure was associated with downregulation of some proteins, namely HSPA5, RCN1, whose expression is upregulated during ER stress conditions [60, 61]. Interestingly, PDIA6 protein expression has been observed to be affected by palmitate exposure in a recently published study [53].

In conclusion, the present study describes the phytochemical composition of different chemotypes of Stevia rebaudiana and demonstrates a role of Stevia extracts, but not of 


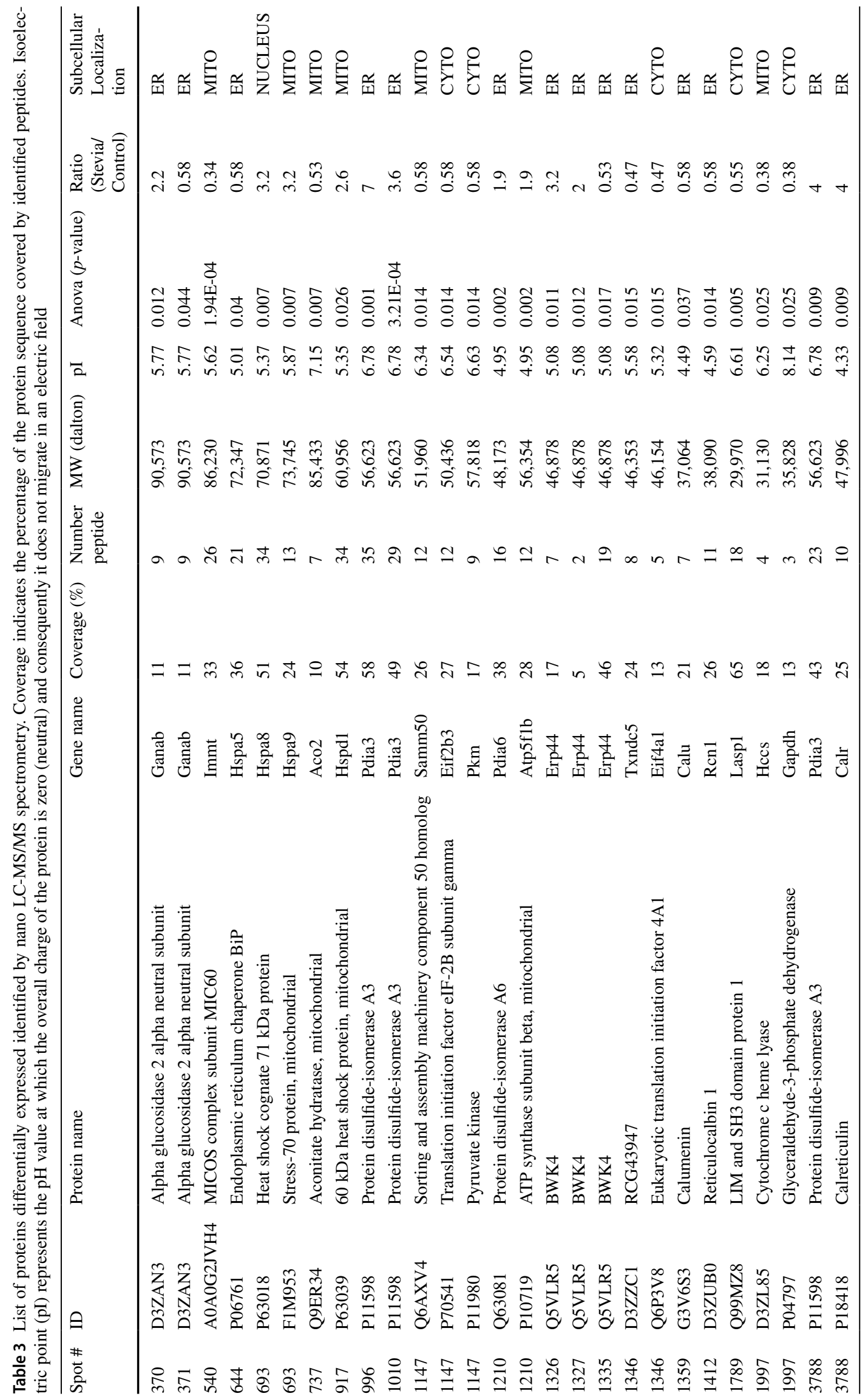




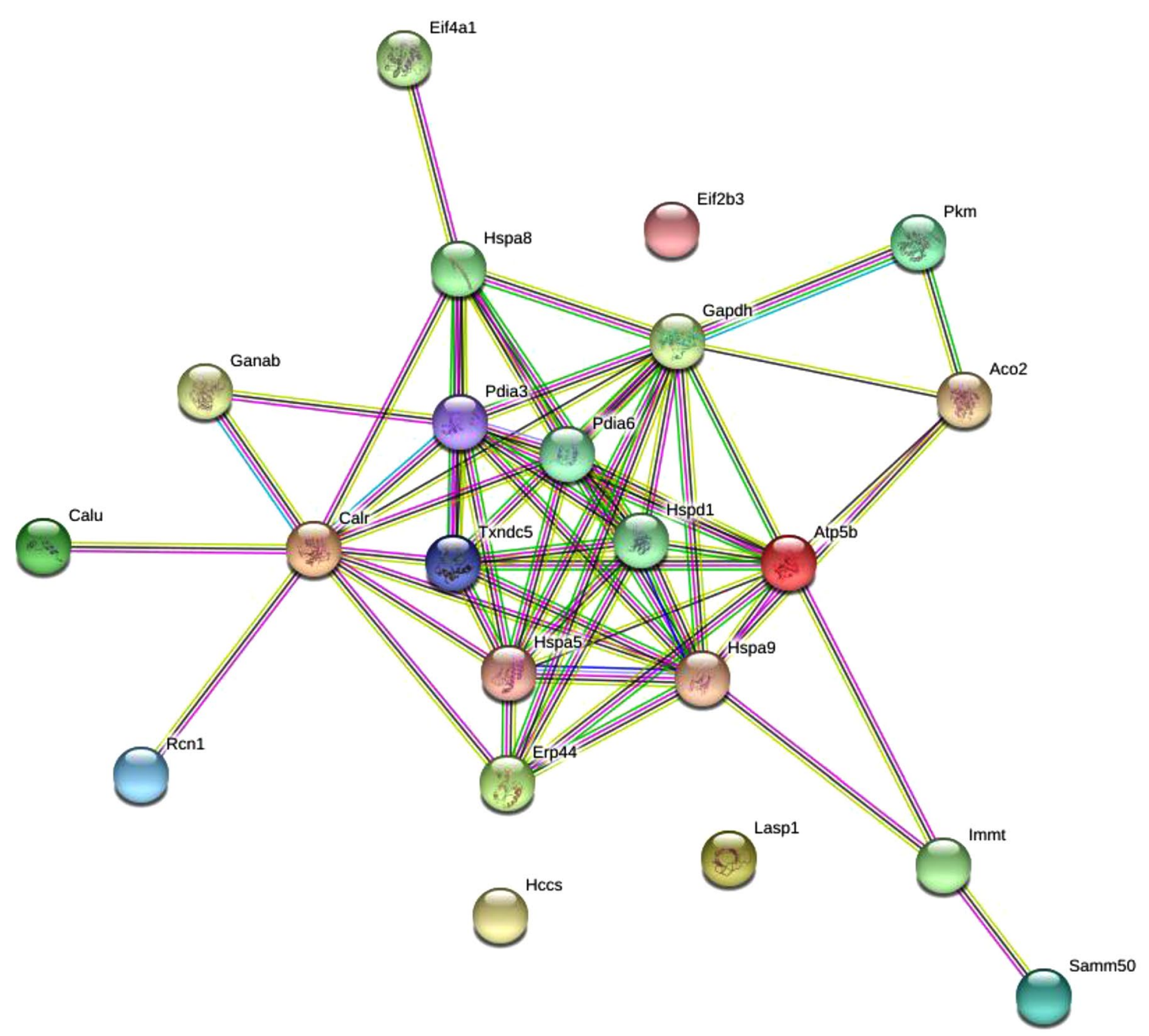

Nodes:

Network nodes represent proteins

splice isoforms or post-translational modifications are collapsed, i.e. each node represents all the proteins produced by a single, protein-coding gene locus.

\section{Node Color}

(8) colored nodes:

query proteins and first shell of interactors

white nodes:

second shell of interactors
Node Content

empty nodes:

proteins of unknown $3 D$ structure

filled nodes:

some $3 D$ structure is known or predicted

\section{Edges:}

Edges represent protein-protein associations

associations are meant to be specific and meaningful, i.e. proteins jointly contribute to a shared function, this does not necessarily mean they are physically binding each other.
Known Interactions

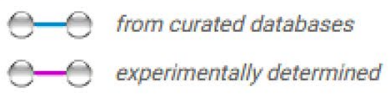

Predicted Interactions

$\bigcirc-O$ gene neighborhood

$\Theta-\bigcirc$ gene fusions

-O gene co-occurrence
Others

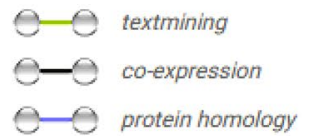

Fig. 6 Predicted protein-protein interactions map of differentially expressed proteins after ST3 treatment of INS-1E beta cells. The interaction map was generated using STRING online tool with default parameters. Network nodes represent proteins. Edges represent protein-protein associations. Confidence view was assigned a score of 0.4 , indicating medium confidence. The two top biological pro- cesses were protein folding and response to stress with a false discovery rate (FDR) value of $11.6 \mathrm{e}^{-4}$ and $4.0 \mathrm{e}^{-4}$, respectively. Network stats: number of nodes, 22; number of edges, 59; average node degree, 5.36; average local clustering coefficient, 0.558; expected number of edges, 6; Protein-protein interaction (PPI) enrichment $p$-value, $<10 \mathrm{e}^{-15}$ 
stevioside alone, on beta-cell survival protection under lipotoxic condition. This action does likely involve the ER and the mitochondrion. Whereas more studies are needed to fully clarify the mechanisms of action of Stevia on beta cells, our results foster additional efforts aiming to further assess the role of Stevia and its components on beta-cell turnover, to possibly contribute to the prevention and/or better treatment of type 2 diabetes.

Acknowledgments We thank Dr. Sandra Mossuto, Dr. Mara Suleiman, Dr. Carmela De Luca, Dr. Lorella Marselli for their technical assistance and Prof. Maria Mazzoni and Prof. Antonio Lucacchini for writing assistance.

Author's contributions L.G.A., P.M., A.M. contributed to conceptualization; L.G.A., P.M., M.B., S.T. contributed methodology; M.B., S.T., F.G., L.G., M.R. contributed to formal analysis; M.B., S.T., F.G., S.L., L.G., M.R. contributed to investigation; S.T., M.B., S.To. contributed to resources; M.B., S.T., M.R. contributed to data curation; S.T., M.B. contributed to writing-original draft preparation; L.G.A., P.M., M.T. contributed to writing-review and editing L.G.A., P.M., A.M. contributed to supervision L.G.A. contributed to project administration L.G.A., P.M., A.M. contributed to funding acquisition. All authors have read and agreed to the published version of the manuscript.

Funding Open access funding provided by Università di Pisa within the CRUI-CARE Agreement. This work was supported and promoted by Aboca s.p.a. Società Agricola and by the 2017 Fund for Basic Research Activities (FFABR-2017) from the Italian Ministry of Education, University and Research (MIUR 2017). PM contribution was supported by PRIN 2015.

\section{Declarations}

Conflicts of interest S.To. and A.M. are involved in Aboca s.p.a. Società Agricola. The remaining authors declare to not have conflict of interest.

Ethics Standard Statement Processing was performed with the approval of the local ethics committee of Pisa University.

Informed consent Pancreata for research purposes were obtained from organ donors after written consent by next-of-kin.

Open Access This article is licensed under a Creative Commons Attribution 4.0 International License, which permits use, sharing, adaptation, distribution and reproduction in any medium or format, as long as you give appropriate credit to the original author(s) and the source, provide a link to the Creative Commons licence, and indicate if changes were made. The images or other third party material in this article are included in the article's Creative Commons licence, unless indicated otherwise in a credit line to the material. If material is not included in the article's Creative Commons licence and your intended use is not permitted by statutory regulation or exceeds the permitted use, you will need to obtain permission directly from the copyright holder. To view a copy of this licence, visit http://creativecommons.org/licenses/by/4.0/.

\section{References}

1. American Diabetes Association (2021) 2. Classification and diagnosis of diabetes: standards of medical care in diabetes-2021. Diabetes Care 44:S15-S33. https://doi.org/10.2337/dc21-S002

2. Halban PA, Polonsky KS, Bowden DW et al (2014) $\beta$-cell failure in type 2 diabetes: postulated mechanisms and prospects for prevention and treatment. Diabetes Care 37:1751-1758. https://doi. org/10.2337/dc14-0396

3. Marchetti P, Suleiman M, De Luca C et al (2020) A direct look at the dysfunction and pathology of the $\beta$ cells in human type 2 diabetes. Semin Cell Dev Biol 103:83-93. https://doi.org/10. 1016/j.semcdb.2020.04.005

4. Cnop M, Abdulkarim B, Bottu G et al (2014) RNA sequencing identifies dysregulation of the human pancreatic islet transcriptome by the saturated fatty acid palmitate. Diabetes 63:19781993. https://doi.org/10.2337/db13-1383

5. Prentki M, Peyot M-L, Masiello P, Madiraju SRM (2020) Nutrient-induced metabolic stress, adaptation, detoxification, and toxicity in the pancreatic $\beta$-Cell. Diabetes 69:279-290. https://doi.org/ 10.2337/dbi19-0014

6. Weir GC, Marselli L, Marchetti P et al (2009) Towards better understanding of the contributions of overwork and glucotoxicity to the beta-cell inadequacy of type 2 diabetes. Diabetes Obes Metab 11(Suppl 4):82-90. https://doi.org/10.1111/j.1463-1326. 2009.01113.x

7. Vilchis-Flores LH, Barajas-Medina GA, Villa-Martínez AK et al (2019) Pancreatic $\beta$-cell dysfunction in normoglycemic patients and risk factors. Acta Diabetol 56:1305-1314. https://doi.org/10. 1007/s00592-019-01411-9

8. Marselli L, Piron A, Suleiman M et al (2020) Persistent or transient human $\beta$ cell dysfunction induced by metabolic stress: specific signatures and shared gene expression with type 2 diabetes. Cell Rep 33:108466. https://doi.org/10.1016/j.celrep.2020.108466

9. Carnovale C, Dassano A, Mosini G et al (2020) The beta-cell effect of verapamil-based treatment in patients with type 2 diabetes: a systematic review. Acta Diabetol 57:117-131. https://doi. org/10.1007/s00592-019-01370-1

10. Kurek JM, Krejpcio Z (2019) The functional and health-promoting properties of Stevia rebaudiana Bertoni and its glycosides with special focus on the antidiabetic potential - a review. J Funct Foods 61:103465. https://doi.org/10.1016/j.jff.2019.103465

11. Hajihashemi S, Geuns JMC (2013) Free radical scavenging activity of steviol glycosides, steviol glucuronide, hydroxytyrosol, metformin, aspirin and leaf extract of Stevia rebaudiana. Free Radicals and Antioxidants 3:S34-S41. https://doi.org/10.1016/j. fra.2013.10.001

12. Abbas Momtazi-Borojeni A, Esmaeili S-A, Abdollahi E, Sahebkar A (2017) A review on the pharmacology and toxicology of steviol glycosides extracted from stevia rebaudiana. Curr Pharm Des 23:1616-1622. https://doi.org/10.2174/13816128226661610211 42835

13. Philippaert K, Pironet A, Mesuere M et al (2017) Steviol glycosides enhance pancreatic beta-cell function and taste sensation by potentiation of TRPM5 channel activity. Nat Commun 8:14733. https://doi.org/10.1038/ncomms14733

14. Ritu M, Nandini J (2016) Nutritional composition of Stevia rebaudiana, a sweet herb, and its hypoglycaemic and hypolipidaemic effect on patients with non-insulin dependent diabetes mellitus. J Sci Food Agric 96:4231-4234. https://doi.org/10.1002/jsfa.7627

15. Hossain MS, Alam MB, Asadujjaman M, et al (2011) Antihyperglycemic and antihyperlipidemic effects of different fractions of Stevia rebaudiana leaves in alloxan induced diabetic rats. Int J Pharm Sci Res 2: 1722. https://doi.org/10.13040/IJPSR.09758232.2(7).1722-29 
16. Kujur RS, Singh V, Ram M et al (2010) Antidiabetic activity and phytochemical screening of crude extract of stevia rebaudiana in alloxan-induced diabetiis rats. Pharmacog J 2:27-32. https://doi. org/10.4103/0974-8490.69128

17. Akbarzadeh S, Eskandari F, Tangestani $\mathrm{H}$ et al (2015) The effect of stevia rebaudiana on serum omentin and visfatin level in STZinduced diabetic rats. J Dietary Suppl 12:11-22. https://doi.org/ 10.3109/19390211.2014.901999

18. Milani PG, Piovan S, Lima YC et al (2021) Whey protein enriched with Stevia rebaudiana fraction restores the pancreatic function of streptozotocin induced diabetic rats. J Food Sci Technol 58:805810. https://doi.org/10.1007/s13197-020-04799-3

19. He J, Zhu N-L, Kong J et al (2019) A newly discovered phenylethanoid glycoside from Stevia rebaudiana Bertoni Affects Insulin Secretion in Rat INS-1 Islet $\beta$ Cells. Molecules 24:125. https:// doi.org/10.3390/molecules24224178

20. Tavarini S, Sgherri C, Ranieri AM, Angelini LG (2015) Effect of nitrogen fertilization and harvest time on steviol glycosides, flavonoid composition, and antioxidant properties in stevia rebaudiana bertoni. J Agric Food Chem 63:7041-7050. https://doi.org/10. 1021/acs.jafc.5b02147

21. Rojas E, Bermúdez V, Motlaghzadeh Y et al (2018) Stevia rebaudiana Bertoni and its effects in human disease: emphasizing its role in inflammation, atherosclerosis and metabolic syndrome. Curr Nutr Rep. https://doi.org/10.1007/s13668-018-0228-z

22. Ahmad U, Ahmad RS (2018) Anti diabetic property of aqueous extract of Stevia rebaudiana Bertoni leaves in Streptozotocininduced diabetes in albino rats. BMC Complement Altern Med 18:179. https://doi.org/10.1186/s12906-018-2245-2

23. Assaei R, Mokarram P, Dastghaib S et al (2016) Hypoglycemic effect of aquatic extract of stevia in pancreas of diabetic rats: PPAR $\gamma$-dependent regulation or antioxidant potential. Avicenna J Med Biotechnol 8:65-74

24. Misra H, Soni M, Silawat N et al (2011) Antidiabetic activity of medium-polar extract from the leaves of Stevia rebaudiana Bert. (Bertoni) on alloxan-induced diabetic rats. J Pharm Bioallied Sci 3:242-248. https://doi.org/10.4103/0975-7406.80779

25. Piovan S, Pavanello A, Peixoto GML et al (2018) Stevia nonsweetener fraction displays an insulinotropic effect involving neurotransmission in pancreatic islets. Int J Endocrinol 2018:3189879. https://doi.org/10.1155/2018/3189879

26. Wölwer-Rieck U (2012) The leaves of Stevia rebaudiana (Bertoni), their constituents and the analyses thereof: a review. J Agric Food Chem 60:886-895. https://doi.org/10.1021/jf2044907

27. Chen J, Jeppesen PB, Nordentoft I, Hermansen K (2007) Stevioside improves pancreatic beta-cell function during glucotoxicity via regulation of acetyl-CoA carboxylase. Am J Physiol Endocrinol Metab 292:E1906-E1916. https://doi.org/10.1152/ajpendo. 00356.2006

28. Chen J, Jeppesen PB, Nordentoft I, Hermansen K (2006) Stevioside counteracts beta-cell lipotoxicity without affecting acetyl CoA carboxylase. Rev Diabet Stud 3:178-188. https://doi.org/10. 1900/RDS.2006.3.178

29. Gregersen S, Jeppesen PB, Holst JJ, Hermansen K (2004) Antihyperglycemic effects of stevioside in type 2 diabetic subjects. Metabolism 53:73-76. https://doi.org/10.1016/j.metabol.2003.07. 013

30. Jeppesen PB, Gregersen S, Poulsen CR, Hermansen K (2000) Stevioside acts directly on pancreatic $\beta$ cells to secrete insulin: Actions independent of cyclic adenosine monophosphate and adenosine triphosphate-sensitive $\mathrm{K}$-channel activity. Metabolism 49:208-214. https://doi.org/10.1016/s0026-0495(00)91325-8

31. Jeppesen PB, Gregersen S, Alstrup KK, Hermansen K (2002) Stevioside induces antihyperglycaemic, insulinotropic and glucagonostatic effects in vivo: studies in the diabetic
Goto-Kakizaki (GK) rats. Phytomedicine 9:9-14. https://doi.org/ 10.1078/0944-7113-00081

32. Jeppesen PB, Gregersen S, Rolfsen SED et al (2003) Antihyperglycemic and blood pressure-reducing effects of stevioside in the diabetic Goto-Kakizaki rat. Metabolism 52:372-378. https://doi. org/10.1053/meta.2003.50058

33. Zimmermann BF, Woelwer-Rieck U, Papagiannopoulos M (2012) Separation of steviol glycosides by hydrophilic liquid interaction chromatography. Food Anal Methods 5:266-271. https://doi.org/ 10.1007/s12161-011-9229-x

34. Tavarini S, Passera B, Martini A et al (2018) Plant growth, steviol glycosides and nutrient uptake as affected by arbuscular mycorrhizal fungi and phosphorus fertilization in Stevia rebaudiana Bert. Ind Crops Prod 111:899-907. https://doi.org/10.1016/j.indcrop. 2017.10.055

35. Dewanto V, Wu X, Adom KK, Liu RH (2002) Thermal processing enhances the nutritional value of tomatoes by increasing total antioxidant activity. J Agric Food Chem 50:3010-3014. https:// doi.org/10.1021/jf0115589

36. Barros L, Heleno SA, Carvalho AM, Ferreira ICFR (2010) Lamiaceae often used in Portuguese folk medicine as a source of powerful antioxidants: vitamins and phenolics. LWT - Food Sci Technol 43:544-550. https://doi.org/10.1016/j.lwt.2009.09.024

37. Benzie IFF, Strain JJ (1999) [2] Ferric reducing/antioxidant power assay: direct measure of total antioxidant activity of biological fluids and modified version for simultaneous measurement of total antioxidant power and ascorbic acid concentration. Methods Enzymol 299:15-27. https://doi.org/10.1016/s00766879(99)99005-5

38. Marselli L, Suleiman M, Masini M et al (2014) Are we overestimating the loss of beta cells in type 2 diabetes? Diabetologia 57:362-365. https://doi.org/10.1007/s00125-013-3098-3

39. Martino L, Masini M, Novelli M et al (2012) Palmitate activates autophagy in INS-1E $\beta$-cells and in isolated rat and human pancreatic islets. PLoS ONE 7:e36188. https://doi.org/10.1371/ journal.pone.0036188

40. Cunha DA, Igoillo-Esteve M, Gurzov EN et al (2012) Death protein 5 and p53-upregulated modulator of apoptosis mediate the endoplasmic reticulum stress-mitochondrial dialog triggering Lipotoxic rodent and human -cell apoptosis. Diabetes 61:2763-2775. https://doi.org/10.2337/db12-0123

41. Skrzypski M, Khajavi N, Mergler S et al (2015) TRPV6 channel modulates proliferation of insulin secreting INS-1E beta cell line. Biochimica et Biophysica Acta (BBA) - Molecular Cell Research 1853:3202-3210. https://doi.org/10.1016/j.bbamcr. 2015.09.012

42. Fiory F, Lombardi A, Miele C et al (2011) Methylglyoxal impairs insulin signalling and insulin action on glucose-induced insulin secretion in the pancreatic beta cell line INS-1E. Diabetologia 54:2941-2952. https://doi.org/10.1007/s00125-011-2280-8

43. Ciregia F, Bugliani M, Ronci M et al (2017) Palmitate-induced lipotoxicity alters acetylation of multiple proteins in clonal $\beta$ cells and human pancreatic islets. Sci Rep 7:13445. https://doi.org/10. 1038/s41598-017-13908-w

44. Ciregia F, Giusti L, Da Valle Y et al (2013) A multidisciplinary approach to study a couple of monozygotic twins discordant for the chronic fatigue syndrome: a focus on potential salivary biomarkers. J Transl Med 11:243. https://doi.org/10.1186/ 1479-5876-11-243

45. Solimena M, Schulte AM, Marselli L et al (2018) Systems biology of the IMIDIA biobank from organ donors and pancreatectomised patients defines a novel transcriptomic signature of islets from individuals with type 2 diabetes. Diabetologia 61:641-657. https://doi.org/10.1007/s00125-017-4500-3

46. Marroqui L, Masini M, Merino B et al (2015) Pancreatic $\alpha$ cells are resistant to metabolic stress-induced apoptosis in type 2 
diabetes. EBioMedicine 2:378-385. https://doi.org/10.1016/j. ebiom.2015.03.012

47. Lytrivi M, Castell A-L, Poitout V, Cnop M (2020) Recent insights into mechanisms of $\beta$-Cell Lipo- and Glucolipotoxicity in type 2 diabetes. J Mol Biol 432:1514-1534. https://doi.org/10.1016/j. jmb.2019.09.016

48. Cosson P, Hastoy C, Errazzu LE et al (2019) Genetic diversity and population structure of the sweet leaf herb, Stevia rebaudiana B, cultivated and landraces germplasm assessed by EST-SSRs genotyping and steviol glycosides phenotyping. BMC Plant Biology. https://doi.org/10.1186/s12870-019-2061-y

49. Angelini LG, Martini A, Passera B, Tavarini S (2018) Cultivation of Stevia rebaudiana Bertoni and associated challenges. Sweeteners. https://doi.org/10.1007/978-3-319-27027-2_8

50. Luppi P, Drain N, To R et al (2020) Autocrine C-peptide protects INS1 $\beta$ cells against palmitic acid-induced oxidative stress in peroxisomes by inducing catalase. Endocrinol Diabetes Metab 3:e00147. https://doi.org/10.1002/edm2.147

51. Li X-D, He S-S, Wan T-T, Li Y-B (2021) Liraglutide protects palmitate-induced INS-1 cell injury by enhancing autophagy mediated via FoxO1. Mol Med Rep. https://doi.org/10.3892/mmr. 2020.11786

52. Wingard RE Jr, Brown JP, Enderlin FE et al (1980) Intestinal degradation and absorption of the glycosidic sweeteners stevioside and rebaudioside A. Experientia 36:519-520. https://doi.org/10. 1007/BF01965774

53. Lytrivi M, Ghaddar K, Lopes $M$ et al (2020) Combined transcriptome and proteome profiling of the pancreatic $\beta$-cell response to palmitate unveils key pathways of $\beta$-cell lipotoxicity. BMC Genomics 21:590. https://doi.org/10.1186/s12864-020-07003-0

54. Magnoni R, Palmfeldt J, Hansen J et al (2014) The Hsp60 folding machinery is crucial for manganese superoxide dismutase folding and function. Free Radic Res 48:168-179. https://doi.org/10.3109/ 10715762.2013.858147
55. Turano C, Gaucci E, Grillo C, Chichiarelli S (2011) ERp57/ GRP58: a protein with multiple functions. Cell Mol Biol Lett 16:539-563. https://doi.org/10.2478/s11658-011-0022-z

56. Gorasia DG, Dudek NL, Safavi-Hemami H et al (2016) A prominent role of PDIA6 in processing of misfolded proinsulin. Biochim Biophys Acta 1864:715-723. https://doi.org/10.1016/j.bbapap.2016.03.002

57. Urquhart KR, Zhao Y, Baker JA et al (2016) A novel heat shock protein alpha 8 (Hspa8) molecular network mediating responses to stress- and ethanol-related behaviors. Neurogenetics 17:91-105. https://doi.org/10.1007/s10048-015-0470-0

58. Finka A, Sharma SK, Goloubinoff P (2015) Multi-layered molecular mechanisms of polypeptide holding, unfolding and disaggregation by HSP70/HSP110 chaperones. Front Mol Biosci 2:29. https://doi.org/10.3389/fmolb.2015.00029

59. Anelli T, Alessio M, Mezghrani A et al (2002) ERp44, a novel endoplasmic reticulum folding assistant of the thioredoxin family. EMBO J 21:835-844. https://doi.org/10.1093/emboj/21.4.835

60. Pobre KFR, Poet GJ, Hendershot LM (2019) The endoplasmic reticulum (ER) chaperone $\mathrm{BiP}$ is a master regulator of ER functions: getting by with a little help from ERdj friends. J Biol Chem 294:2098-2108. https://doi.org/10.1074/jbc.REV118.002804

61. Xu S, Xu Y, Chen L et al (2017) RCN1 suppresses ER stressinduced apoptosis via calcium homeostasis and PERK-CHOP signaling. Oncogenesis 6:e304. https://doi.org/10.1038/oncsis. 2017.6

Publisher's Note Springer Nature remains neutral with regard to jurisdictional claims in published maps and institutional affiliations. 